International Association for the Psychology of Language Learning (IAPLL)

Journal for the Psychology of Language Learning

ISSN: 2642-7001. http://www.iapll.com/journal

Issue 1, June 2019, pp. 67-82

\title{
Thoughts on the Launching of a New Journal: A Complex Dynamic Systems Perspective
}

Diane Larsen-Freeman, University of Michigan and University of Pennsylvania, USA

\begin{abstract}
The launching of The Journal for the Psychology of Language Learning is a signal achievement. I begin this commentary by speculating on why it is that the Psychology of Language Learning (PLL) has enjoyed such vigor of late. I expect that one reason is the coming together of a critical mass of researchers and strong leaders over their shared interests. A second reason may be that a new way of looking at familiar phenomena was introduced in the form of complex dynamic systems theory (CDST). Building on this supposition, I proceed to recommend extending CDST thinking in some new ways in PLL. These ways are phenomenological, relational, processual, and transdisciplinary. I conclude by urging the PLL community to remain connected with other areas of applied linguistics so that it may continue to contribute to a knowledge-building community.
\end{abstract}

Keywords: CDST, phenomenological, relational, processual, transdisciplinary

Congratulations to the Psychology of Language Learning (PLL) academic community for establishing a new organization (International Association for the Psychology of Language Learning), convening an innovative conference series (PLL Conferences), and for launching this new journal-all indicators of the vibrancy of the community.

"New beginnings are opportunities and the launching of a new journal is no exception." Inspired by this statement from Nesselroade and Ram (2004, p. 9), I would like to use the opportunity afforded me by the editors of this journal to engage in a bit of "goal directing," as Nesselroade calls it, or to put it more modestly, to invite PLL researchers to consider some extensions of CDST thinking. 
This bold aim stems in part from my interest in understanding the source of PLL's relatively new vitality and my hope that it will be sustained. After all, robust research programs on motivation, anxiety, learning strategies, willingness to communicate, etc. have existed for some time. Indeed, individual difference (ID) research has been undertaken since the beginning of the SLA field, inspired, if only indirectly, by the differential success question posed by Hatch (1974). One is left wondering, then, why PLL has garnered such recent attention, as evidenced, for example, by the proliferation of research reports, including most recently the proceedings from PLL 3 (Mynard \& Brady, 2019). I believe that there are two reasons for its vigor.

First, it seems to me that it takes 'a critical mass' of researchers, with a similar orientation and some strong leaders to generate such enthusiasm. I witnessed this happen with the social challenge to the cognitivist understanding of second language development (SLD $\left.{ }^{1}\right)$ at the end of the last century. Social views of SLD were not previously unknown. Indeed, Vygotskyan sociocultural theory and Labovian-inspired sociolinguistic views of SLA had been around for decades, and Conversation Analysis researchers had been active in second language research since the 1970s. Nonetheless, it was a pivotal moment at the end of the 1990s, when a 'critical mass' of socially-oriented researchers gathered together at AILA 1994 to introduce a major new perspective, one that challenged the prevailing cognitive "mainstream" position.

The second reason for the transformation from a more cognitive understanding of SLD to a more socially embedded one is that the challengers presented not simply a broader way of construing the SLD process, but a new ontology (Larsen-Freeman, 2007). For instance, Firth and Wagner (1997, p. 286) challenged foundational concepts in SLA, principally the idea of the nonnative speaker, the learner, and interlanguage. In the same way, I believe it was the embrace of complex dynamic systems theory (CDST) by certain PLL researchers that helped spur PLL to become the vibrant community that it is today. ${ }^{2} \mathrm{CDST}$ provided a new way of thinking about individual differences (Dörnyei, MacIntyre, \& Henry, 2015; Larsen-Freeman, 2015). No longer static and independent variables, individual differences were seen to be emergent, dynamic and interconnected (de Bot, Lowie, \& Verspoor, 2007; Larsen-Freeman \& Cameron, 2008).

\footnotetext{
${ }^{1}$ A term that I prefer to second language acquisition because a teleological understanding does not tell the story of the process.

${ }^{2}$ For the latest, see the symposium at PLL3, entitled "Simply researching complexity in language learning and teaching” with Sampson, Pinner, Falout, \& Yashima, in Mynard \& Brady, 2019) and Castro (2019).
} 
I realize that many in the PLL community are well-acquainted with tenets of CDST and their application to ID's (see, for example, the recognition of the convergence between Positive Psychology and CDST by Li, Dewaele, \& Jiang, 2019), so I do not wish to review them here. Instead, I will use this opportunity to introduce some extensions of CDST-inspired ideas. By no means do I intend for the link between PLL and CDST to be an exclusive undertaking or to silence other perspectives. In fact, to be true to CDST, a both... and perspective is much more in accord (Larsen-Freeman, 2017). Or perhaps a many... and. Deleuze (1994) reminds us that scholarship doesn't advance because we wholly reject what has come before. Instead, he advises, scholars should adopt attitudes of "and, and, and." Nevertheless, I think that such a link to CDST would contribute to the current momentum enjoyed by the PLL community.

Candidly speaking, there is another reason for my recommendation. The rise of an academic community is accompanied by a responsibility. In my opinion, PLL must not retreat unto itself by holding its own conferences, with members only publishing in its own journal, thereby becoming isolated from academics with other interests. This would be a most unfortunate turn of events in my opinion. It seems to me that retaining a connection to other areas of applied linguistics would be facilitated by sharing a discourse, for after all, CDST has been taken up by many applied linguists (Larsen-Freeman, 2017). I will revisit this position later.

For now, let me highlight several CDST developments that I believe PLL researchers should consider in order to maintain the connectedness and continue to contribute to a knowledge-building community. They are phenomenological, relational, processural, and transdisciplinary.

\section{Individual $\rightarrow$ Person-oriented $\rightarrow$ Phenomenological}

Many scholars, at least implicitly, have taken the stance that SLA should be the study of individuals. ${ }^{3}$ I will cite Tomlin (1990, p. 157) for doing so forthrightly:

\footnotetext{
${ }^{3}$ It important to acknowledge by encouraging the study of individual learners, I by no means want to discredit the characterization of the learner as a social being. Indeed, it can be said that an individual's "becoming" is in interaction with others. Nonetheless, it is also possible for the individual to get lost when we consider the social. As Duff and Doherty (2015) have noted, there can be a tendency to overemphasize the social determination of language learning behavior.
} 
SLA is a problem of individuals. A proper account of SLA must be an account of how individuals learn second languages. Second language acquisition is a phenomenon of the individual—not of a collective — even though acquisition cannot occur outside a social context.

In point of fact, the field of second language development can be traced back to the study of individuals: the pioneering diary accounts by Ronjat (1913) of his son Louis and Leopold of his daughter Hildegard (1949). In fact, many of the early investigations of SLD were case studies (see, e.g., Hatch, 1978). Beyond these early examples, it is certainly true that studies of individuals have been influential beyond what their $n$ of 1 would appear to warrant because they have acted as "correctives" to well-accepted claims about SLD. For instance, Ioup, Boustagui, Tigi, and Moselle's (1994) Julie was an adult native speaker of British English, living in Cairo, who was said to speak Egyptian Arabic in a way virtually indistinguishable from native speakers of Arabic; thus, Julie's Arabic-speaking ability can be adduced as counter-evidence to the critical period hypothesis. ${ }^{4}$

So it is not the case that individuals have been ignored in SLA research. However, ironically, while the research on individual differences (IDs) would seem to be a place where the individual is in focus, this is not so. For all its considerable value, ID research usually examines groups of learners purported to share (or not) some variable. In such research, the individual is not central. ${ }^{5}$ By categorizing individuals, we lose sight of what makes them unique. Indeed, bound by the ergodic theorems (Molenaar \& Campbell, 2009), it is understood that no individual conforms to the mean of any group. "The one thing that is known for certain is that the average is not good enough if the goal is to understand individuals: We must explain patterns of individual variability" (Verspoor, Lowie, \& van Dijk, 2008, p. 152).

In order to understand the SLD of individuals, researchers have typically relied on qualitative approaches, e.g., diary studies, ethnography, narrative inquiry (e.g., Benson, 2014) and more recently autoethnography (Choi, 2017). However, quantitative and mixed methods (see, e.g., Pfenninger \& Singleton, 2016) can also be useful in this regard (Hiver \& Al-Hoorie,

\footnotetext{
${ }^{4}$ For other examples of case studies that have acted as correctives, see Larsen-Freeman (2019).

${ }^{5}$ It goes without saying that there may be a legitimate reason to conduct sample-based research in order to make statistical generalizations about groups. This is the case with language policy makers, for instance (van Geert \& Steenbeek, 2014).
} 
2016; forthcoming). And, what is noteworthy these days is the new degree of interest shown the individual, perhaps ironically through the use of "big data." Indeed, a science centered on individual variability has contributed an important perspective in many fields, including cell biology, cancer, neuroscience, and psychology. ${ }^{6}$ For instance, every day one reads about some new personalized treatment, such as immunotherapy, which trains cancer patients' own T cells to attack the malignant ones. "The main goal of this kind of therapy is that patients are treated as individuals instead of as 'members of a population"” writes psychologist von Eye (2010, p. 277).

Along the same lines, a recent article in the New York Times ('The AI Diet' March 3, 2019) by cardiologist Eric Topol proclaimed that we know very little about the science of nutrition, but clearly, there is no one diet optimal for all, which is why so many diets fail. A universal diet denies the remarkable heterogeneity of human metabolism, microbiome, and environment, among other factors. Topol concludes that a good diet has to be individualized, and one way of doing so is to rely on AI to "crunch billions of pieces of data about each person."

Obviously, applied linguists are not in a position to make use of big data to tailor instruction, given the nascence of PLL findings, and perhaps they never will be; nevertheless, psychologist Reitzle (2013) declares that it is time to bring the individual back into developmental research. Reitzle claims that the well-known tribulations of modern day psychological research can be overcome by starting with a more appropriate idiographic perspective.

Of course, as I have suggested with my "both... and" statement, there is a place in SLD for both idiographic and nomothetic research. Still, I think it behooves us to make a further distinction in psychology between "idiographic" and "person."

[These days] person-oriented research [in psychology] is being discussed in two forms. One is labeled idiographic psychology...the other person-oriented psychology...The fundamental tenet of both approaches states that premature aggregation of data can result in conclusions that fail to do justice to the variability in populations.

(von Eye \& Spiel, 2010, p. 151)

\footnotetext{
${ }^{6}$ Of course, big data can also pose a threat to privacy, security, and dignity (Raymond, 2019).
} 
Importantly, “...the person-oriented approach views the person as a holistic unit rather than a sum of his or her characteristics, and thus, it provides an alternative or complementary approach to the more traditional, variable-oriented approaches...” (Knisely \& Drauker, 2016, p. 508).

In SLD, this approach has been represented by Ushioda's (2009) call for a move towards a person-in-context, relational view of motivation, which understands "motivation as emergent from relations between real persons" (2009, p. 215) and her (2016) call for viewing motivation through a "small lens." What Ushioda (2009, p. 220) makes clear is the need "to focus on real persons, rather than on learners as theoretical abstractions; a focus on the agency of the individual person as a thinking, feeling human being, with an identity, a personality, a unique history and background, a person with goals, motives and intentions..." Most recently, such sentiments have been expressed by MacIntyre, Gregersen, and Mercer (2019, p. 262): "Languages are both taught and learned by people — human beings with hopes and fears, strengths and limitations, goals and frustrations."

If this is the goal, and I think it should be, then it seems to me that (at least some) researchers should make the whole person the focus of their studies (see Mercer, 2011). One word of caution is in order, though, and that is for researchers to avoid the temptation to look across studies of 'whole people' in order to identify common patterns. While the impulse to do just this is natural enough, Haggis (2008) warns against such a practice. She observes that in the search for common patterns, we tend to make the differences among people invisible. Another serious concern is the decontextualizing both in space and time that results from the search for cross-person themes. Haggis also reminds us that if one adopts a CDST perspective, one needs to keep in mind emergence - the notion that,

every dynamic system is unique, in that even similar types of system will have emerged out of slightly different combinations of original interactions; will have 'initial conditions' that consisted of specific combinations of the many different interactions which were theoretically possible at that time and in that place; and will have specific histories which involve further particular interactions with particular combinations of factors. (Haggis, 2008, p. 8) 
"In one word, person-oriented research does not proceed from the assumption that the validity of concepts and variables is universal. Person-oriented research is open to the assumption that particular concepts exist in or apply to particular populations or even individuals only."

(von Eye \& Spiel, 2010, p. 153)

I am frankly uncertain at this point concerning whether or not one can find categories or profiles of homogeneous subgroups of learners with regards to IDs (see, for example, Papi \& Teimouri, 2014), but I agree with Steinberg (2015) when he notes that researchers still have the responsibility for going beyond the particular instances of their research, and I am currently working on and thinking about this tension between uniqueness and generalizability (LarsenFreeman, forthcoming). One well-known position on this issue can already be found in van Geert (2011, p. 276) when he explains that a single case study can be generalizable, depending on how it links to a particular theory. "For students of language development, single case studies have a direct bearing on the underlying theory, and only an indirect one on the population of language learners."

In commenting on CDST, Ortega and Han (2017, p. 3) put it this way: "Empirical observations must be generalizable to ideas and principles, but always by staying grounded in the particularities of individual systems as they interact and self-adapt with one another and with context in reciprocal, not fully predictable ways."

In studying the unique 'particularities' of individuals and even persons, a further step can be taken: bringing a phenomenological perspective to bear (e.g., Ros i Solé, 2016). Because consciousness and intentionality can only be experienced from a first-person point of view, such a view should inform the interpretation of our research findings, I believe. It seems to me that in order to understand language learners as persons, we must think in terms of what I have called "second order affordances," (Larsen-Freeman, 2016), not what learning opportunities are available, i.e., first order affordances, but which opportunities learners perceive and act on. As Mercer (2012, p. 43) states, "The learner makes personal sense out of what they encounter and uses affordances in ways that are personally meaningful and relevant."

Interviewing learners using stimulated recall is one such means that has been used effectively (e.g., Gregersen, MacIntyre, \& Meza, 2014) to get at what is valid from a first-person point of view. Another approach is using the idiodynamic method (MacIntyre \& Legatto, 2011). 
A third example is a dialogic approach to a research interview (Harvey, 2015). Perhaps less wellknown than the first two, this last example involves the researcher and the researched conversing about the researcher's findings, not simply for the purposes of strengthening the validity of the researcher's data interpretations by "member checking," but because as researcher Harvey (2015, p. 24 ) opines, "I felt that if I was to genuinely see the people I am working with, and myself, as responsible, thinking agents, I had a responsibility to give them the opportunity to theorize their own experience." And, for this reason, she engages with her participants in "dynamic coconstruction" (p. 35) of a final research report.

Also related to person-centered holism as seen through the prism of phenomenology is the relational quality of complex dynamic systems.

\section{Relational}

The prevailing ethos of CDST lies in non-reductionist systems thinking, specifically recognizing the interconnectedness of the components of a system and their interface with what is external to it (Hiver \& Larsen-Freeman, forthcoming). For this reason, CDST insists on studying complex systems within the temporal-spatial context they occupy where "interrelationships are at least as important as the components themselves" (Monat \& Gannon, 2015, p. 24).

The way that the 13th century Sufi poet, Jalaluddin Rumi, put it is "You think because you understand 'one' that you must therefore understand 'two' because one and one make two. But you forget that you must also understand 'and." In other words, understanding a complex system requires relational thinking, more than understanding each member or component of the system atomistically.

It also requires the understanding that relationships change with time. One component of a complex system may be ascendant, while another declines. To make this more concrete, we can hypothesize that as a learner's attitude about studying another language improves, the learner may be more willing to communicate. This systems view has not gone unrecognized in PLL research. For example, De Ruiter, Elahi Shirvan, and Talehzadeh (2019) report on the dynamic relationship between students' experiences of anxiety and enjoyment during second-language learning given the dynamics of their teachers' changing emotional support. 
The PLL community has been slower to take up another important dimension to relational thinking. As early as 2003, Dörnyei commented that motivation has had a rather marginalized existence in SLA because it has had little to say about how the psychology of motivation relates to the actual processes and intricacies of linguistic development, which was the preoccupation in SLA (see also Ushioda, 2010). Obviously, the explanandum has broadened considerably since, no longer restricted to formal linguistic development; however, I am not sure that the divide has been bridged.

It would be most welcome if the PLL field worked towards uniting the two prongs of the bifurcated agenda (learning process and individual differences) for SLA that has existed since its modern-day inception. It seems to me that this can be done with longitudinal case studies, in which both the process and individual differences are studied relationally (Hepford, 2017) and when the data collection is optimally dense (Evans, 2018) so as not to overlook any possible significant incidents (Pigott, 2019).

An additional relationship to appreciate is that between the researcher and the researched. Certainly, no one entertaining a CDST perspective could ascribe an apartness to the researcher. In an early study on the effects of Benzodiazepine on the ego permeability of language learners, Guiora, Acton, Erard, and Strickland (1980) determined that it was not the drug that influenced behavior of the participants, but rather the effect of having been tested by a particular research assistant. It was clear in their study that a participant's score was significantly influenced by the individual who did the testing and that this susceptibility to influence became more powerful as dosage increased. Clearly, more attention needs to be given to the relationship between the researcher and research participants.

\section{The Dynamics of Change $\rightarrow$ Processual Questions}

Of course, it has been recognized for some time that IDs are mutable over time (Dörnyei, 2009). In the move from a variable-centered investigation to a person-centered one, it would be useful to recall what is said about complex systems: They are in the process of becoming, not being. As Giordano (2017, p. 507) puts it:

A key idea embedded in the notion of the interdependent self is not only that it relational (which it is), but that it is inherently particularistic and contextual. Even to describe the relational self as a "self" or as "it" is, to a degree, misleading. The 
label of a processual, transitory, or always-emergent "self"' is more apropos, as it does a better job of expressing a Becoming ontology.

I presume that a becoming ontology underlies the thinking in Gregersen and MacIntyre's (2014) book, Capitalizing on Language Learners' Individuality, in which they state that "Language learning psychology is not a hard-wired state but rather is a dynamic and complex process in which psychological traits cannot (or should not) be permanently assigned to any learner."

MacIntyre and Gregersen (2019) provide a very useful example for clarifying the contrast between static IDs measured at one time and a CDST one; they suggest a rephrasing of a research question as follows: Whereas a traditional research question might be 'Does language anxiety correlate with course grades?', rephrased from a CDST perspective, it would be 'What happens as anxiety rises during a test?' I think such processual questions should be encouraged in PLL research.

\section{Psychology $\rightarrow$ Multidisciplinary $\rightarrow$ Transdisciplinary}

Earlier, I expressed my concern that the PLL researchers not isolate themselves from other academics as I have observed researchers in other areas of applied linguistics do. Indeed, it seems to me that the wider field has become increasingly fractionated, ironically so in this time of increased connectivity.

One way to keep work on the psychology of the language learner being relational (and thus not "tribal") is to engage in multidisciplinary research. To be clear, I am not asking anyone to change their primary identity, as a psychologist, an educator, a teacher educator, etc., but rather to enjoin their unique perspective with that of others to forge multidisciplinary teams. Duff (2019) offers another example from medicine. For instance, when treating a patient with cancer, teams with different specializations are convened:

general practitioners, surgeons, pathologists, medical and radiation oncologists, hematologists, geneticists, genomic researchers, physical therapists, nutritionists, social workers, counselors, etc. - offer analytical, diagnostic, and therapeutic perspectives on 
the patient's case, but without necessarily having deep, current expertise in each other's areas of specialization (which are constantly evolving, as are their own).

$$
\text { (Duff, 2019, pp. 28-29) }
$$

In a recent lecture, Cori Bargmann (2019) laid out what she imagined the future of neuroscience to be: It must be open and collaborative for problems that are too difficult for one researcher or for one group of researchers to investigate on their own. Closer to home, Toth (2019) convened a Language Learning Roundtable at the American Association for Applied Linguistics conference in which multiple theoretical perspectives were brought to bear on L2 classroom data from a third-year L2 Spanish class. Each presenter chose to analyze a different facet of the data, but collectively a much richer picture emerged.

Even more, in this era where the structure and categories of disciplinary knowledge themselves are in play (Larsen-Freeman \& Freeman, 2008), it seems that the field of SLD is moving beyond multidisciplinary to transdisciplinary (Douglas Fir Group, 2016), one in which what disciplines have to contribute is respected and distinct, but where the disciplines are "in dialogue with one another in order to address real-world issues" (Douglas Fir Group, 2016, p. 20). The additional benefit of transdisciplinarity is the thematic innovation that they stimulate (Larsen-Freeman, 2012). One of these innovations is Complexity Theory (Halliday \& Burns, 2006).

Again, congratulations are on order to the PLL community, and I wish it well as it breaks new ground in helping us to better understand the psychology of language learning. I also hope that the way of thinking that a CDST perspective engenders makes available a common discourse, not so as to lead to a homogeneity of thought, but rather so that multidisciplinary and transdisciplinary collaboration is facilitated.

\section{Notes on the Contributor}

Diane Larsen-Freeman is a Professor Emerita of Education and of Linguistics at the University of Michigan and a Research Scientist Emerita and former Director of its English Language Institute. She is also a Professor Emerita at the Graduate SIT Institute, Brattleboro, Vermont, and currently, she is a Visiting Senior Fellow at the University of Pennsylvania. 


\section{References}

Bargmann, C. (2019). Organizing behavior across timescales. The $21^{\text {st }}$ Pinkel endowed lecture, University of Pennsylvania, April 19, 2019.

Benson, P. (2014). Narrative inquiry in applied linguistics research. Annual Review of Applied Linguistics, 34, 154-170. doi:10.1017/s0267190514000099

Castro, E. (2019). Motivational dynamics in language advising sessions: A case study. Studies in Self-Access Learning Journal, 10(1), 5-20. Retrieved from https://sisaljournal.org/archives/mar19/castro/

Choi, J. (2017). Creating a multivocal self: Autoethnography as method. New York, NY: Routledge.

de Bot, K., Lowie, W., \& Verspoor, M. (2007). A dynamic systems theory approach to second language acquisition. Bilingualism: Language and Cognition, 10(1), 7-21. doi:10.1017/s1366728906002732

Deleuze, G. (1994). Difference \& repetition. New York, NY: Columbia University Press.

De Ruiter, N. M. P., Elahi Shirvan, M., \& Talebzadeh, N. (2019). Emotional processes of foreign-language learning situated in real time teacher support. Ecological Psychology, 31(2), 127-145. doi:10.1080/10407413.2018.1554368

Dörnyei, Z. (2003). Attitudes, orientations and motivations in language learning: Advances in theory, research and applications. In Z. Dörnyei (Ed.), Attitudes, orientations, and motivation in language learning (pp. 3-32). Oxford, UK: Blackwell.

Dörnyei, Z. (2009). Individual differences: Interplay of learner characteristics and learning environment. In N. C. Ellis \& D. Larsen-Freeman (Eds.), Language as a complex adaptive system (pp. 237-255). Oxford, UK: Wiley Blackwell.

Dörnyei, Z., MacIntyre, P., \& Henry, A. (Eds). (2015). Motivational dynamics in language learning. Bristol, UK: Multilingual Matters.

Douglas Fir Group. (2016). A transdisciplinary framework for SLA in a multilingual world. The Modern Language Journal, 100(S1), 19-47. doi:10.1111/modl.12301

Duff, P. (2019). Social dimensions and processes in second language acquisition: Multilingual socialization in transnational contexts. The Modern Language Journal, 103, 6-22. doi:10.1111/modl.12534

Duff, P., \& Doherty, L. (2015). Examining agency in (second) language socialization research. In P. Deters, X. Gao, E. Miller, \& G. Vitanova (Eds.), Interdisciplinary approaches to theorizing and analyzing agency and second language learning (pp. 54-72). Bristol, UK: Multilingual Matters.

Evans, R. (2018). Bifurcations, fractals, and non-linearity in second language development: A complex dynamic systems perspective. Unpublished Ph.D. dissertation, University of 
Buffalo.

Firth, A., \& Wagner, J. (1997). On discourse, communication, and (some) fundamental concepts in SLA research. The Modern Language Journal, 81(3), 285-300. doi:10.1111/j.15404781.1997.tb05480.x

Giordano, P. (2017). Individual personality is best understood as process, not structure. Culture \& Psychology, 23(4), 502-518. doi:10.1177/1354067x17692118

Gregersen, T., \& MacIntyre, P. D. (2014). Capitalizing on language learner individuality. Bristol, UK: Multilingual Matters.

Gregersen, T., MacIntyre, P. D., \& Meza, M. D. (2014). The motion of emotion: Idiodynamic case studies of learners' foreign language anxiety. The Modern Language Journal, 98(2), 574-588. doi:10.1111/modl.12084

Guiora, A. Z., Acton, W. R., Erard, R., \& Strickland, Jr., F. W. (1980). The effects of Benzodiazepine (Valium) on permeability of language ego boundaries. Language Learning, 30(2), 351-363. doi:10.1111/j.1467-1770.1980.tb00323.x

Haggis, T. (2008) 'Knowledge must be contextual': Exploring some possible implications of complexity and dynamic systems theories for educational research. Educational Philosophy and Theory, 40(1), 158-176. doi:10.1111/j.1469-5812.2007.00403.x

Halliday, M., \& Burns, A. (2006). Applied linguistics: Thematic pursuits or disciplinary moorings? Journal of Applied Linguistics, 3(1), 113-128. doi:10.1558/japl.v3i1.113

Harvey, L. (2015). Beyond member-checking: a dialogic approach to the research interview. International Journal of Research and Method in Education, 38(1), 23-38. doi:10.1080/1743727x.2014.914487

Hatch, E. (1974). Second language learning—universals? Working Papers on Bilingualism, 3, $1-17$.

Hatch, E. M. (1978). Second language acquisition: A book of readings (pp. 401-35). Rowley, MA: Newbury House.

Hepford, E. (2017). Dynamic second language development: The interaction of complexity, accuracy, and fluency in a naturalistic learning context. Unpublished Ph.D. dissertation, Temple University.

Hiver, P., \& Al-Hoorie, A. H. (2016). A dynamic ensemble for second language research: Putting complexity theory into practice. The Modern Language Journal, 100(4), 741756. doi:10.1111/modl.12347

Hiver, P., \& Al-Hoorie, A. H. (forthcoming). Research methods for complexity theory in applied linguistics. Bristol, U.K.: Multilingual Matters.

Hiver, P., \& Larsen-Freeman, D. (forthcoming). Motivation: It is a relational system. In A. H. 
Journal for the Psychology of Language Learning, Issue 1, June 2019, pp. 67. ISSN: 2642-7001. http://www.iapll.com/journal

Al-Hoorie \& P. D. MacIntyre (Eds.), Contemporary language motivation theory: 60 years since Gardner and Lambert (1959). Bristol, UK: Multilingual Matters.

Ioup, G., Boustagui, E., el Tigi, M., \& Moselle, M. (1994). Reexamining the critical period hypothesis. A case study of successful SLA in a naturalistic environment. Studies in Second Language Acquisition, 16(1), 73-98. doi:10.1017/s0272263100012596

Knisely, M. R., Draucker, C. B. (2016). Using a person-oriented approach in nursing research. Western Journal of Nursing Research, 38(4), 508-520. doi:10.1177/0193945915602856

Larsen-Freeman, D. (2007). The cognitive-social debate in second language acquisition. The Modern Language Journal, 94, 773-787. doi:10.1111/j.1540-4781.2007.00668.x

Larsen-Freeman, D. (2012). Complex, dynamic systems: A new transdisciplinary theme for applied linguistics? Language Teaching, 45(2), 202-214. doi:10.1017/s0261444811000061

Larsen-Freeman, D. (2015). Ten lessons from CDST: What is on offer. In Z. Dörnyei, P. D. MacIntyre, \& A. Henry (Eds.), Motivational dynamics in language learning (pp. 11-19). Bristol, U.K.: Multilingual Matters.

Larsen-Freeman, D. (2016). Shifting metaphors: From computer input to ecological affordances to adaptation. In Proceedings from the IATEFL 50 ${ }^{\text {th }}$ Anniversary Conference, Birmingham (pp. 10-19). Kent: IATEFL.

Larsen-Freeman, D. (2017). Complexity theory: The lessons continue. In L. Ortega \& Z-H. Han (Eds.), Complexity theory and language development: In celebration of Diane LarsenFreeman (pp. 11-50). Amsterdam, The Netherlands: John Benjamins.

Larsen-Freeman, D. (2019). On language learner agency: A complex dynamic systems theory perspective. The Modern Language Journal, 103(SI), 61-79. doi:10.1111/modl.12536

Larsen-Freeman, D. (forthcoming). Look to the tides-On predictability and idiosyncrasy in second language learning. A Presentation at The fourth international Psychology of Language Learning conference (PLL4), Cape Breton University, Sydney, Nova Scotia Canada, June 24-28, 2020.

Larsen-Freeman, D., \& Freeman, D. (2008). Language moves: The place of “foreign” languagein classroom teaching and learning. Review of Research in Education, 32(1), 147-186. American Educational Research Association. doi:10.3102/0091732x07309426

Larsen-Freeman, D., \& Cameron, L. (2008). Complex systems in applied linguistics. Oxford, UK: Oxford University Press.

Leopold, W. (1949). Speech development of a bilingual child (Volume 4). Evanston, IL: Northwestern University Press.

Li, C., Dewaele, J.-M., \& Jiang, G. (2019). The complex relationship between classroom emotions and EFL achievement in China. Applied Linguistics Review 2019. doi:10.1515/applirev-2018-0043 
MacIntyre, P. D., \& Legatto, J. J. (2011). A dynamic system approach to willingness to communicate: Developing an idiodynamic method to capture rapidly changing affect. Applied Linguistics, 32(2), 149-171. doi:10.1093/applin/amq037

MacIntyre, P. D., \& Gregersen, T. (2019). Applications of two methods for studying language's dynamic systems: Idiodynamics and Experience Sampling. Paper presented at the American Association for Applied Linguistics, Atlanta, March 11.

MacIntyre, P. D., Gregersen, T., \& Mercer, S. (2019). Setting an agenda for positive psychology in SLA: Theory, practice, and research. The Modern Language Journal, 103(1), 262274. doi:10.1111/modl.12544

Mercer, S. (2011). The self as a complex dynamic system. Studies in Second Language Learning and Teaching, 1(1), 57-82. doi:10.14746/ssllt.2011.1.1.4

Mercer, S. (2012). The complexity of learner agency. Apples - Journal of Applied Language Studies, 6(2), 41-59. Retrieved from http://apples.jyu.fi/article_files/Final_Mercer.pdf

Molenaar, P., \& Campbell, C. G. (2009). The new person-specific paradigm in psychology. Current Directions in Psychological Science, 18(2), 112-117. doi:10.1111/j.14678721.2009.01619.x

Monat, J. P., \& Gannon, T. F. (2015). What is systems thinking? A review of selected literature plus recommendations. American Journal of Systems Science, 4(1), 11-26. doi:10.5923/j.ajss.20150401.02

Mynard, J., \& Brady, I. K. (Eds.) (2019). Stretching boundaries. Papers from the third International Psychology of Language Learning Conference, Tokyo, Japan. 7-10 June, 2018. Tokyo, Japan: IAPLL.

Nesselroade, J. R., \& Ram, N. (2004). Studying intraindividual variability: What we have learned that will help us understand lives in context. Research in Human Development, 1(1-2), 9-29. doi:10.1080/15427609.2004.9683328

Ortega, L., \& Han, Z. (Eds.) (2017). Complexity theory and language development: In celebration of Diane Larsen-Freeman. Amsterdam, The Netherlands: John Benjamins.

Pigott, J. (2019). Anagnorisis and narrative incorporation: How significant incidents affect language-learning behavior. Studies in Second Language Learning and Teaching, 9(1), 177-198. doi:10.14746/ssllt.2019.9.1.8

Papi, M., \& Teimouri, Y. (2014). Language learner motivational types: A cluster analysis study. Language Learning, 64(3), 493-525. doi:10.1111/lang.12065

Pfenninger, S., \& Singleton, D. (2016). Affect trumps age: A person-in-context relational view of age and motivation in SLA. Second Language Research, 32(3), 311-345. doi:10.1177/0267658315624476

Raymond, N. (2019). Reboot ethical review for the age of big data. Nature, 568 (18 April 2019), 277. Retrieved from https://www.nature.com/magazine-assets/d41586-019-01164- 
z/d41586-019-01164-z.pdf

Reitzle, M. (2013). Introduction: Doubts and insights concerning variable and person-oriented approaches to human development. European Journal of Developmental Psychology, 10(1), 1-8. doi:10.1080/17405629.2012.742848

Ronjat, J. (1913). Le développement du langage observé chez un enfant bilingue. Paris, France: H. Champion.

Ros I Solé, C. (2016). The personal world of the language learner. London, UK: Palgrave Macmillan.

Steinberg, P. F. (2015). Can we generalize from case studies? Global Environmental Politics, 15(3), 152-175. doi:10.1162/glep_a_00316

Tomlin, R. (1990). Functionalism in second language acquisition. Studies in Second Language Acquisition, 12(2), 155-177. doi:10.1017/s0272263100009062

Toth, P. (2019). What do the data show? Multiple theoretical perspectives on learning in a single L2 classroom. An Invited Colloquium at the American Association for Applied Linguistics, Atlanta, March 11.

Ushioda, E. (2009) A person-in-context relational view of emergent motivation, self and identity. In Z. Dörnyei \& E. Ushioda (Eds.), Motivation, language identity and the L2 self (pp. 215-228). Bristol, UK: Multilingual Matters.

Ushioda, E. (2010). Motivation and SLA: Bridging the gap. EUROSLA Yearbook 10, 5-20. doi:10.1075/eurosla.10.03ush

Ushioda, E. (2016). Language learning motivation through a small lens: A research agenda. Language Teaching, 49(4), 564-577. doi:10.1017/s0261444816000173

van Geert (2011). The contribution of complex dynamic systems to development. Child Development Perspectives, 5(4), 273-278. doi:10.1111/j.1750-8606.2011.00197.x

van Geert, P., \& Steenbeek, H. (2014). The good, the bad and the ugly? The dynamic interplay between educational practice, policy and research. Complicity: An International Journal of Complexity and Education, 11(2), 22-39. doi:10.29173/cmplct22962

Verspoor, M., Lowie, W., \& van Dijk, M. (2008). Variability in second language development from a dynamic systems perspective. The Modern Language Journal, 92(2), 214-231. doi:10.1111/j.1540-4781.2008.00715.x

von Eye, A. (2010). Developing the person-oriented approach: Theory and methods of analysis. Development and Psychopathology, 22(2), 277-285. doi:10.1017/s0954579410000052

von Eye, A., \& Spiel, C. (2010). Conducting person-oriented research. Journal of Psychology, 218(3), 151-154. doi:10.1027/0044-3409/a000024 